\title{
SEROPREVALENCE AND DETECTION OF AVIAN INFLUENZA TYPE A IN DUCKS AT NIKLI AND BAJITPUR UPAZILA OF BANGLADESH
}

\author{
M. Z. Hassan ${ }^{1 *}$, B. C. Das ${ }^{2}$, M. S. Mahmud ${ }^{1}$, M. A. Amin' ${ }^{2}$, M. A. Yousuf' ${ }^{1}$, M. Jaber' ${ }^{2}$, S. M. S. H. Belal' ${ }^{2}$, \\ M. A. Hasan ${ }^{1}$, A. Hossen ${ }^{1}$, M. R. Karim ${ }^{1}$, M. S. Rahman ${ }^{3}$ and M. F. Hoque ${ }^{3}$ \\ ${ }^{\mathbf{1}}$ Bangladesh Livestock Research Institute, Savar, Dhaka-1341; ${ }^{2}$ Department of Livestock Services, Dhaka \\ ${ }^{3}$ Department of Medicine, Surgery and Obstetrics, Hajee Mohammad Danesh Science and Technology \\ University, Dinajpur-5200, Bangladesh
}

\begin{abstract}
Waterfowl are the natural reservoir of avian influenza viruses and ducks may play a role in the maintenance of avian influenza type A. The aim of the present study was to investigate the seroprevalence and detection of avian influenza virus (AIV) type A in duck. This study was carried out during July 2013 to December 2013 on AIV type A from semi-scavenging farm at Nikli and Bajitpur upazila of Kishoregonj district in Bangladesh. A total of 368 blood samples were collected from duck and tested by indirect ELISA for seroprevalence. For detection of AIV type A, The cloacal swabs were collected from 75 duck and subjected to RNA extraction and real time RT-PCR (rRT-PCR) with specific primer and probe for detection of matrix (M) gene. The average seroprevalance of AIV type A in seven different age groups was found to be $90.21 \%$. The highest $(25.81 \%)$ seroprevalence was found in 5 months age of birds and the lowest $(2.44 \%)$ was found in 12 months age of birds. As regard to area distribution, the average degree of seroprevalence was $93.51 \%$ from Nikli had the highest order than Bajitpur (86.88\%) upazila of Bangladesh. In case of cloacal sample by using rRT-PCR, out of 15 pooling cloacal samples, two pooling samples (13.33\%) that contain 10 samples were positive and 13 pooling samples showed negative (86.67\%) for AIV type A in duck. It can be concluded that the long distance movement of duck flocks, may influence outbreak of avian influenza virus (AIV) type A among different poultry species in Bangladesh. Therefore, it needs to develop control strategy for future dissemination of AIV in duck population.
\end{abstract}

Key words: Avian influenza virus, duck, seroprevalence, ELISA, rRT-PCR

\section{INTRODUCTION}

Avian Influenza, also known as fowl plague, is a potentially devastating disease, predominantly of chickens, ducks and turkeys, although the virus can also affect game birds (pheasants, partridge and quail), ratites (ostrich and emu), psittacine and passerine birds (Alexander, 2000). Avian influenza (AI) viruses are type A orthomyxoviruses in the family Orthomyxoviridae, which includes four genera: Influenza A, B and C viruses and Thogotovirus, as recently proposed by the International Committee on Taxonomy of Viruses (ICTV), (Wright and Webster, 2001) They are enveloped negative-stranded RNA viruses that can be distinguished on the basis of antigenic differences in nucleocapsid $(\mathrm{N})$ and matrix $(\mathrm{M})$ proteins (Lamb and Krug, 2001) AI viruses are further divided into 16 hemagglutinin [H(1-16)] and 9 neuraminidase [N(1-9)] subtypes based on hemagglutinin inhibition and neuraminidase inhibition tests, respectively. Most AI viruses [H (1-16)] subtypes) are of low pathogenicity, but some of the $\mathrm{H} 5$ and $\mathrm{H} 7 \mathrm{AI}$ viruses are highly pathogenic for chickens, turkeys, and related gallinaceous domestic poultry.

Influenza A viruses infecting poultry can be divided into two distinct groups on the basis of their ability to cause disease in chickens. The very virulent viruses cause 'fowl plague', now termed highly pathogenic avian Influenza (HPAI), in which mortality may be as high as 100\%. These viruses have been restricted to subtypes H5 and H7, although not all viruses of these subtypes cause HPAI. All other viruses cause a much milder, primarily respiratory disease designated low pathogenicity avian influenza (LPAI), which, nevertheless, may be exacerbated by other infections or environmental conditions resulting in a much more serious disease. Influenza viruses have a high error rate during the transcription of their genomes because of the low RNA polymerase fidelity (Parvin et al., 1986; Stech et al., 1999).

*Corresponding e-mail address: zhtitas@gmail.com

Copyright $@ 2015$ Bangladesh Society for Veterinary Medicine

All rights reserved 0320/2015 


\section{Z. Hassan and others}

The high error rate produces a quasispecies phenomenon where many different viral genotypes will co circulate in the host, with each virus potentially having different levels of fitness for the host environment (Domingo et al., 1985).

Waterfowl are the natural reservoir of avian influenza viruses (Webster et al., 1992), and experimental research indicates that ducks may play a role in the maintenance of HPAI (H5N1) viruses. Infected ducks may exhibit no clinical signs yet can excrete high concentrations of virus that are pathogenic to other poultry species (Chen $e t$ al., 2004; Hulse-Post et al., 2005 and Sturm-Ramirez et al., 2005). Possible risk factors for HPAI spread in Indonesia include duck movements, contacts between ducks and other poultry and animal species, poor poultry husbandry, inadequate handling of sick and dead ducks by flock owners, and poor awareness of control strategies among poultry farmers. However, no analytical study assessing risk factors for HPAI infection has been conducted in Indonesia.

AI viruses may be present in village or backyard flocks and other birds sold through live-poultry markets. Infected birds can shed avian influenza A viruses in their saliva, nasal secretions, and feces. Susceptible birds become infected when they have contact with the virus as it is shed by infected birds. They also can become infected through contact with surfaces that are contaminated with virus from infected birds. Avian influenza viruses are readily transmitted from farm to farm by the movement of domestic live birds, people (especially when shoes and other clothing are contaminated), and contaminated vehicles, equipment, feed, and cages.

In Bangladesh, HPAI had been identified for the first time in March 2007 by National Reference Laboratory for Avian Influenza (NRL-AI) after passing a long immediate risk period which was reconfirmed by the International Reference Laboratory in UK and a regional laboratory in Thailand (Alam et al., 2010). Long border of India and Myanmar is surrounding Bangladesh. Open water bodies in Bangladesh are shared by large number of migratory waterfowl and domestic semi-scavenging ducks during winter season. As a result, the domestic ducks might get AIVs from migratory waterfowls and might act as a natural reservoir of AIVs without showing clinical disease. In fact, Bangladesh, with duck stocks of 38.1 million, has the third largest duck population in the world (Ahmed et al., 2012). Also, small scale commercial poultry farms with poor bio-security are widespread throughout the country in addition to household village chicken. Many households keep chickens and ducks on same premises (Ahmed et al., 2012) and domestic semi-scavenging ducks are often in close contact with poultry, livestock, and humans in the same property. Therefore, domestic ducks may play a major role in the ecology of AIVs in Bangladesh and may act as potential vessels for their genetic re-assortment (Ahmed et al., 2012) and thus demand active surveillance. Unfortunately, most of the information regarding influenza infection in Bangladesh has focused on passive surveillance of backyard or commercial farms (Biswas et al., 2008; Biswas et al., 2009) relying on poultry farmers to report suspected outbreaks of HPAI. Recently, an active surveillance for AIV on live bird markets of Bangladesh has been conducted and seven LPAI virus strains have been isolated with predominantly $\mathrm{H} 9 \mathrm{~N} 2$ strains and $\mathrm{H} 5 \mathrm{~N} 1$ strain has been observed at extremely low prevalence (Negovetich et al., 2011).

This study primarily details influenza infection in semi-scavenging ducks surrounding two important haor sites of Bangladesh because of the hypothesized role that the semi-scavenging domestic ducks play on the epidemiology of AIV. In view of above considering facts the present the research work was undertaken to determine seroprevalence of avian influenza type A with indirect ELISA from different age group and detection of AI virus by rRT-PCR in semi-scavenging domestic ducks.

\section{MATERIALS AND METHODS \\ Study area}

This study was conducted in two different surrounding haor sites located in rural areas of Bajitpur and Nikli Upazila under Kishoreganj District (Figure 1), Bangladesh during the period of July 2013 to December 2013. The samples were collected from domestic ducks (Khaki Cambel, Nageswhari and native duck) reared on semiscavenging farming system and brought to the Central Disease Investigation Laboratory (CDIL), Dhaka, for laboratory analysis. 


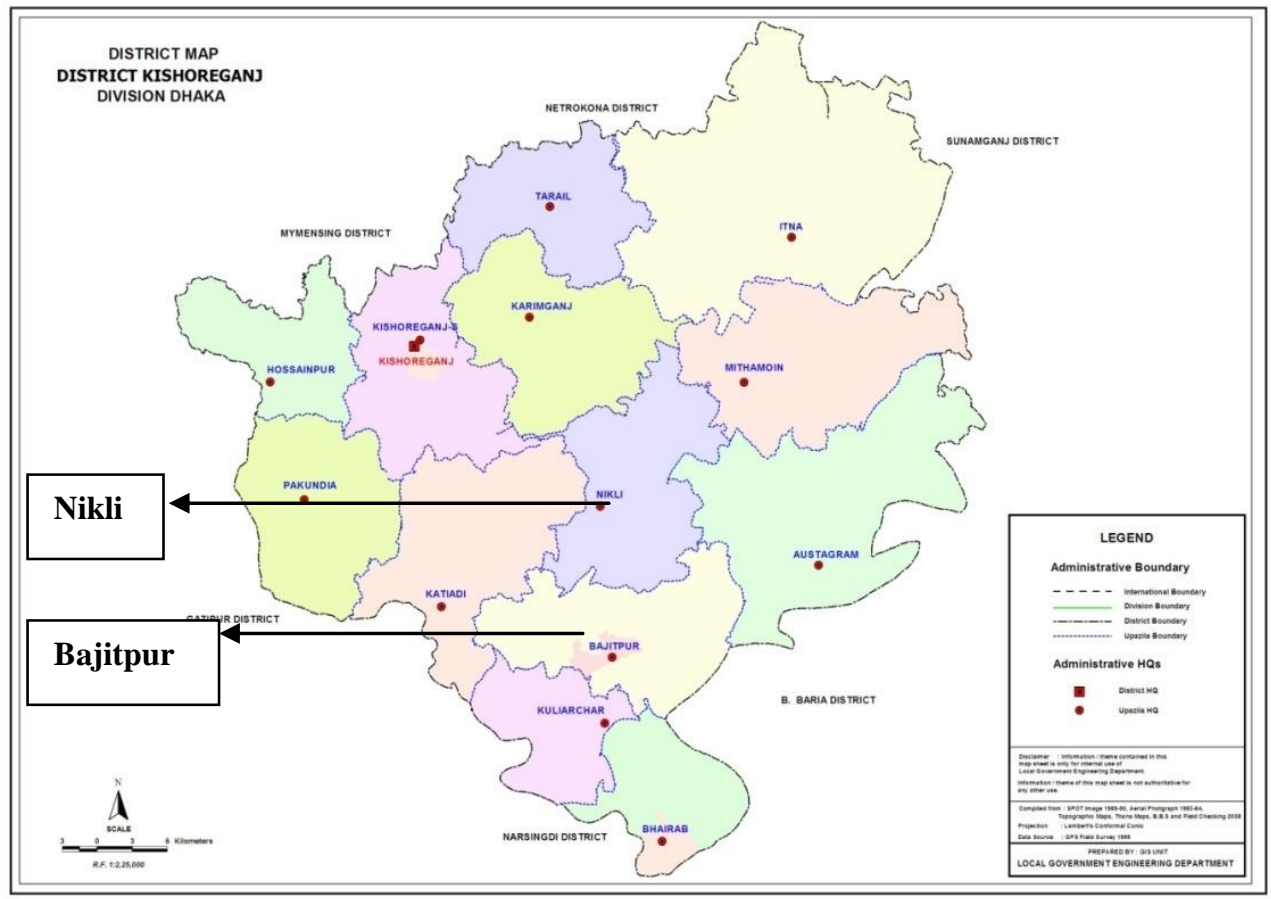

Fig 1. Sample collection area of Bajitpur and Nikli Upazila in Kishoreganj District

\section{Sample collection}

For seroprevalence study, a total of 368 blood samples from the wing vein of individual ducks. Seven different age groups were categorized collected from two selected area. Blood samples were aseptically collected in sterile vial with sterile 5-mL syringe and the samples were allowed to clot in the syringe and kept for 30 minutes to 1 hour at room temperature. After clotting, sera were separated, centrifuged $(12,000 \mathrm{rpm}, 1$ minute) at room temperature and poured in sterile vials, individually labeled, and stored at $-20^{\circ} \mathrm{C}$ until further use.

For detection of AI virus, a total of 75 cloacal swab samples were collected from ducks. Sterile cotton swab sticks were used for sample collection. Samples for virus isolation were collected in viral transport medium [VTM (Hank's balanced salt solution with Penicillin, Streptomycin, Gentamycin, Amphotericin B)], immediately sealed and transported in cold chain to the laboratory. Aseptic precautions like wearing latex gloves, facemasks and correct disposal of used equipment were carried out [Pawar et al., 2009 and WHO, 2002]. All cloacal samples were pooling as 1: 5 and made total 15 (For 75 samples) pooling cloacal swab samples.

\section{Indirect Enzyme linked Immunosorbant Assay (ELISA)}

Antibodies of avian influenza A virus were detected by using commercially available enzyme-linked immunosorbent assay (ELISA) kits (IDEXX, Portland, ME, USA). The procedure for ELISA was followed according to the protocol suggested by the manufacturer. Each serum sample was diluted 1:500 in the accompanied sample diluent and $100 \mu \mathrm{l}$ diluted serum was used for testing. The results were read using an ELISA reader and the data were recorded accordingly. The data were subsequently analyzed using FLOCKCHEK software provided by IDEXX. A sample containing ELISA antibody titres $\geq 500$ was considered positive.

\section{Real-time reverse transcriptase polymerase chain reaction (rRT-PCR)}

RNA was extracted with the RNeasy kit (Qiagen, Valencia, CA). The Qiagen onestep RT-PCR kit (Qiagen Inc., Valencia, CA) was used with a $20 \mu \mathrm{l}$ reaction volume with the following conditions: 10 pmol each primer, 


\section{Z. Hassan and others}

$0.3 \mathrm{lM}$ hydrolysis probe, $3.75 \mathrm{mM} \mathrm{MgCl} 2$ and 2.5 units RNase inhibitor (Promega, Madison, WI). The primer and probe sequences are in Table 1. All hydrolysis probes were labeled at the $5^{\prime}$ end with 6-carboxyflourescein (FAM) as the reporter dye and at the 3' end with carboxy tetramethylrhodamine (TAMRA) as the quencher dye. The following thermal profile was used: a single cycle of reverse transcription for $30 \mathrm{~min}$ at $45^{\circ} \mathrm{C}, 2 \mathrm{~min}$ at $95^{\circ} \mathrm{C}$ for reverse transcriptase inactivation and DNA polymerase activation followed by 40 amplification cycles of 15 sec at $95^{\circ} \mathrm{C}$ and $1 \mathrm{~min}$ at $60^{\circ} \mathrm{C}$ each (annealing-extension step). Triplicate negative and positive controls were included in each experiment. Each fluorescent reporter signal was measured against the internal reference dye (ROX) signal to normalize for non-PCR-related fluorescence fluctuations between samples. The data were collected at the annealing step of each cycle and the threshold cycle $(\mathrm{Ct})$ for each sample was calculated by determining the point at which the fluorescence exceeded the threshold limit. The standard curve was calculated automatically by plotting the $\mathrm{Ct}$ values against each standard of known concentration and by extrapolating the linear regression line of this curve.

Table 1. rRT-PCR primer and probe sequences of AIV type A

\begin{tabular}{|c|c|c|}
\hline $\begin{array}{l}\text { Primer/probe } \\
\text { name }\end{array}$ & Sequence & Reference \\
\hline $\mathrm{M}+25$ & $5^{\prime}$-AGA TGA GTC TTC TAA CCG AGG TCG-3' & Spackman et al. (2003) \\
\hline M-124 & 5'-TGC AAA AAC ATC TTC AAG TCT CTG-3' & \\
\hline M+64 & 5'- FAM-TCA GGC CCC CTC AAA GCC GA-TAMRA-3' & \\
\hline
\end{tabular}

\section{RESULTS AND DISCUSSION}

A total of 368 blood serum sample swabs and 75 cloacal sample were collected from semi-scavenging and back yard ducks from two upazila, Nikli and Bajitpur of Kishoreganj district in Bangladesh during September 2013 to November 2013. All sera samples were tested with indirect ELISA, in which 332 were test positive and 36 were test negative for avian influenza type A. The overall seroprevalence was recorded as $90.21 \%$ that were sero-positive for avian influenza type A antibody. The highest $(25.81 \%)$ prevalence was found in 5 months age of birds and the lowest $(2.44 \%$ ) was found in 12 months age of birds (Table 2). Seroprevalence of different age groups was also found difference of immune status at various age groups of birds.

Table 2. Seroprevalence of AI on different age groups in Duck

\begin{tabular}{|c|c|c|c|c|c|}
\hline \multirow{2}{*}{$\begin{array}{l}\text { Total Tested } \\
\text { Sample }\end{array}$} & \multirow[t]{2}{*}{ Age (Month) } & \multicolumn{2}{|c|}{ ELISA Positive Result } & \multicolumn{2}{|c|}{ ELISA Negative Result } \\
\hline & & Positive & Percentage & Negative & Percentage \\
\hline \multirow{7}{*}{368} & 4.5 & 38 & $10.39 \%$ & 4 & $1.08 \%$ \\
\hline & 5 & 95 & $25.81 \%$ & 5 & $1.35 \%$ \\
\hline & 5.5 & 64 & $17.39 \%$ & 8 & $2.17 \%$ \\
\hline & 6 & 72 & $19.51 \%$ & 6 & $1.63 \%$ \\
\hline & 8 & 30 & $8.15 \%$ & 9 & $2.44 \%$ \\
\hline & 10 & 24 & $6.52 \%$ & 3 & $0.81 \%$ \\
\hline & 12 & 9 & $2.44 \%$ & 1 & $0.27 \%$ \\
\hline Total & & 332 & $90.21 \%$ & 36 & $9.79 \%$ \\
\hline
\end{tabular}

To determine the distribution of AIV, the average degree of seroprevalence was $93.51 \%$ from Nikli had the highest order than Bajitpur (86.88\%) upazila of Bangladesh (Table 3). For detection of avian influenza type A, a total of 75 cloacal swab samples were collected from semi-scavenging domestic ducks of two different districts of Bangladesh. From 75 samples, 15 pooling samples (1:5) were prepared and subjected to real time RT-PCR for detection of matrix $(\mathrm{M})$ gene. Out of 15 pooling cloacal samples, two pooling samples (13.33\%) that contain 10 samples were positive and 13 pooling samples showed negative $(86.67 \%)$ for AIV type A as determined by real 
time RT-PCR (Fig. 2). Asymptomatic domestic ducks can shed the virus continuously from the oral cavity and cloaca (Songserm et al., 2006; Hulse-Post et al., 2005; Sturm-Ramirez et al., 2005).

Table 3. Distribution of AIV type A at two different upazila of Bangladesh

\begin{tabular}{llllll}
\hline Name of Upazila & \multirow{2}{*}{ Serum sample } & \multicolumn{2}{c}{ Test positive (+ve) } & \multicolumn{2}{c}{ Test Negative (-ve) } \\
\cline { 3 - 6 } & & Sample & Prevalence & Sample & Percentage \\
\hline Nikli & 185 & 173 & $93.51 \%$ & 12 & $6.49 \%$ \\
Bajitpur & 183 & 159 & $86.88 \%$ & 24 & $13.12 \%$ \\
Total & 368 & 332 & $90.21 \%$ & 36 & $9.79 \%$ \\
\hline
\end{tabular}

rRT-PCR was chosen as an alternative method of AIV detection because it offers advantages over conventional RT-PCR. The advantages of rRT-PCR over conventional RT-PCR include speed and the reduced chance of cross-contamination among samples because no post amplification sample handling is necessary. Additionally, the labeled probe used to detect the PCR product with real-time PCR methods is target specific, providing an additional level of confirmation that the PCR product is the expected target, as compared to conventional RTPCR. The positive result implies it posses the Avian Influenza Virus can remain in the environment and has possibility to infect surrounding poultry and other birds (Islam et al., 2012). Although we did not perform sub typing of the isolates, it is assumed from the recent study on live bird market that new subtypes of AIV, with various combinations of hemagglutinins and neuraminidase, are currently circulating (Khatun et al., 2013).

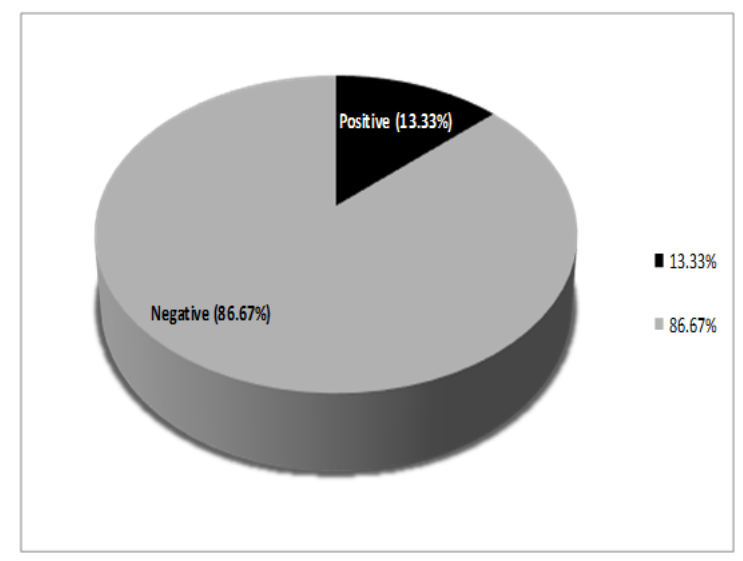

Fig. 2. Percentage of AIV type A from pooling sample of Duck

Assessment of HPAI movement across continents is of great concern to researchers working with AIV because of the panzootic HPAI with H5N1 viruses in Asia. Influenza surveillance in Bangladesh began in 2007 and was focused on the commercial and backyard farms only (Gilbert et al., 2006). All these surveillance are mostly passively on the poultry farmers to report suspected outbreaks of HPAI. However, very little information is available regarding the occurrence of AIV in domestic ducks in Bangladesh. In a study detected AIV in the cloacal swabs (6.2\% cases) in haor ducks during late autumn and early winter and indicated infectivity of ducks. This annual temporal pattern is similar that occurs in Northern Europe (Wallensten et al., 2007) and North America (Krauss et al., 2004). Here we concentrated our study on the active surveillance for AIV in semi- 


\section{Z. Hassan and others}

scavenging ducks to find out their role in AIV epidemiology. Results of our current study indicate that semiscavenging ducks might be a source of infection for poultry in Bangladesh which is posses almost similar result of (Islam et al., 2012). The overall AIV type A positive cases were recorded as 332 out of 368 blood serum samples and the prevalence rate was $90.21 \%$ which is higher rate than (Khatun et al., 2013) and recent prevalence report on live bird market in Bangladesh (Negovetich et al., 2011).

With respect to wintering sites, highest prevalence was reported from swab collected surrounding the haor area in the largest marsh wet land ecological system of Eastern Bangladesh and one where in millions of migratory waterfowls harbor during winter season. Therefore, it is possible that larger number of semi-scavenging and backyard ducks get infected from migratory water fowls during sharing the same water bodies. This factor may contribute to the infection of the native chickens and further on to the commercial chickens (Alexander, 1993).

Our study suggests that the epicenter of the AIV outbreaks was the Nikli and Bajitpur upazila of Kishoregonj district in Bangladesh and semi-scavenging domesctic ducks was the primary source of infection. We concluded here that the present study on semi-scavenging domestic ducks for Avian influenza virus (AIV) type A in Bangladesh that increases our understanding on the ecology and epidemiology of AIVs. Continuous monitoring and rapid detection of AIV in duck is necessary to combat the spread of this virus.

\section{ACKNOWLEDGEMENTS}

The authors are thankful to the Central Disease Investigation Laboratory (CDIL), Department of Livestock Services, Dhaka, Bangladesh to support this research.

\section{REFERENCES}

1. Ahmed SS, Ersbøll AK, Biswas PK, Christensen JP, Hannan AS and Toft N (2012). Ecological determinants of highly pathogenic avian influenza (H5N1) outbreaks in Bangladesh. PLoS One 7: e33938.

2. Alam J, Giasuddin M, Samad MA and Taimur MJFA (2010). Recent evidence of Avian Influenza in Bangladesh: a review. World's Poultry Science journal 66: 455-464.

3. Alexander DJ (1993). Orthomyxovirus infections. Viral infections of vertebrates 3: 287-316.

4. Alexander DJ (2000). A review of avian influenza in different bird species. Veterinary microbiology 74: 3-13.

5. Biswas PK, Christensen JP, Ahmed SS, Barua H, Das A, Rahman MH, Giasuddin M, Hannan AS, Habib MA and Ahad A (2008). Avian influenza outbreaks in chickens, Bangladesh. Emerging infectious diseases 14: 1909-1912.

6. Biswas PK, Christensen JP, Ahmed SS, Das A, Rahman MH, Barua H, Giasuddin M, Hannan AS, Habib MA and Debnath NC (2009). Risk for infection with highly pathogenic avian influenza virus (H5N1) in backyard chickens, Bangladesh. Emerging Infectious Diseases 15: 1931-1936.

7. Chen H, Deng G, Li Z, Tian G, Li Y, Jiao P and Yu K (2004). The evolution of H5N1 influenza viruses in ducks in southern China. Proceedings of the National Academy of Sciences of the United States of America 101: 1045210457.

8. Domingo E, Martinez SE, Sobrino F, de la Torre JC, Portela A, Ortin J, Lopez Galindez C, Perez- Brena P, Villanueva N and Najera R (1985). The quasispecies (extremely heterogeneous) nature of viral RNA genome populations: biological relevance - a review. Gene 40: 1-8.

9. Gilbert M, Chaitaweesup P, Parakamawongsa T, Premashthira S, Tiensin T, Kalpravidh W and Slingenbergh J (2006). Free-grazing ducks and highly pathogenic avian influenza, Thailand. Emerging infectious diseases 12: 227 234.

10. Hulse-Post DJ, Sturm-Ramirez KM, Humberd J, Seiler P, Govorkova EA, Krauss S, Scholtissek C, Puthavathana P, Buranathai C and Nguyen T (2005). Role of domestic ducks in the propagation and biological evolution of highly pathogenic H5N1 influenza virus in Asia. Proceedings of the National Academy of Sciences of the United States of America 102: 10682-10687.

11. Islam MZ, Ahmed S, Khan SA and Hossain MB (2012). Significance of duck in the transmission of avian influenza virus. University Journal of Zoology, Rajshahi University 30: 77-79.

12. Khatun A, Giasuddin M, Islam KM, Khanom S, Samad MA, Islam MR and Rahman MM (2013). Surveillance of avian influenza virus type A in semi-scavenging ducks in Bangladesh. BMC veterinary research 9: 196.

13. Krauss S, Walker D, Pryor SP, Niles L, Chenghong L, Hinshaw VS and Webster RG (2004). Influenza A viruses of migrating wild aquatic birds in North America. Vector Borne Zoonotic Diseases 4: 177-189. 
14. Lamb RA and Krug RM (2001). Orthomyxoviridae: The viruses and their replication. In: D.M. Knipe, et al. Editors Fields Virology. Philadelphia, PA, USA: Lippincott Williams \& Wilkins, pp. 1487-531.

15. Negovetich NJ, Feeroz MM, Jones-Engel L, Walker D, Alam SM, Hasan K and Webster RG (2011). Live bird markets of Bangladesh: H9N2 viruses and the near absence of highly pathogenic H5N1 influenza. PLoS One 6: e19311-e19311.

16. Parvin JD, Moscona A, Pan WT, Leider JM and Palese P(1986). Measurement of the mutation rates of animal viruses: infuenza A virus and poliovirus type 1. Journal of Virology 59 (2): 377-383.

17. Pawar SD, Pande S, Jamgaonkar A, Koratkar SS, Pal B, Raut S, Nanaware M, Ray K, Chakrabarti AK, Kode SS, Thite V, Khude MR, Randive S, Basu A, Pawashe A, Ponkshe A, Pandit P and Deshpande P (2009). Avian influenza surveillance in wild migratory, resident, domestic birds and in poultry in Maharashtra and Manipur, India, during avian migratory season 2006-2007. Current Science 97: 550-554.

18. Songserm T, Jam-on R, Sae-Heng N, Meemak N, Hulse-Post DJ, Sturm-Ramirez KM and Webster WG (2006). Domestic ducks and H5N1 influenza epidemic, Thailand. Emerging infectious diseases 12: 575-581.

19. Stech J, Xiong X, Scholtissek C and Webster RG (1999). Independence of evolutionary and mutational rates after transmission of avian infuenza viruses to swine. Journal of Virology 73: 1878-1884.

20. Sturm-Ramirez KM, Hulse-Post DJ, Govorkova EA, Humberd J, Seiler P, Puthavathana P, Buranathai C, Nguyen T, Chaisingh A and Long H (2005). Are ducks contributing to the endemicity of highly pathogenic H5N1 influenza virus in Asia? Journal of Virology 79: 11269-11279.

21. Wallensten A, Munster VJ, Latorre-Margalef N, Brytting M, Elmberg J, Fouchier RA, Fransson T, Haemig PD, Karlsson M, Lundkvist A, Osterhaus AD, Stervander M, Waldenström J and Björn O (2007). Surveillance of influenza A virus in migratory waterfowl in northern Europe. Emerging Infectious Disease 13: 404-411.

22. Webster RG, Bean WJ, Gorman OT, Chambers TM and Kawaoka Y (1992). Evolution and ecology of influenza A viruses. Microbiology Review 56: 152-179.

23. World Health Organization (2002). Manual on Animal influenza diagnosis and surveillance (2002) WHO/CDS/CSR/NCS 5: 15-62.

24. Wright PF and Webster RG (2001). Orthomyxoviruses. In: D.E. Griffin, Editors Fields Virology. Philadelphia, PA, USA: Lippincott Williams \& Wilkins, pp. 1533-79. 